\title{
Biology and behaviour of Cirrospilus diallus and Cirrospilus pictus, parasitoids of Phyllocnistis citrella
}

\author{
M. Lo PINTO ${ }^{1, *}$, G. SALERNO ${ }^{2}$ and E. WAJNBERG ${ }^{3}$ \\ ${ }_{1}^{1}$ Dipartimento di Scienze Entomologiche, Fitopatologiche, Microbiologiche agrarie e \\ Zootecniche, Università di Palermo, Viale delle Scienze, 13 -90128, Palermo, Italy; \\ ${ }^{2}$ Dipartimento di Arboricoltura e Protezione delle Piante, Università di Perugia, \\ Borgo XX Giugno, 06121, Perugia, Italy; ${ }^{3}$ INRA, 400 Route des Chappes, BP 167, \\ 06903, Sophia Antipolis Cedex, France \\ *Author for correspondence; e-mail:lopinto@unipa.it
}

Received 20 July 2004; accepted in revised form 13 April 2005

\begin{abstract}
Studies were carried out on some biological and behavioral aspects of Cirrospilus diallus Walker and Cirrospilus pictus (Nees) (Hymenoptera: Eulophidae) in relation to their host, the citrus leafminer (CLM), Phyllocnistis citrella Stainton (Lepidoptera: Gracillariidae). Adults of both species fed with sugar lived on average $4.45 \pm 0.19$ days, whereas adults provided with honey survived on average $40.62 \pm$ 1.97 days. Rates of host mortality due to parasitoid stings without oviposition were as high as 31.25 and $37.73 \%$ for C. pictus and C. diallus, respectively. Both species showed arrhenotokous parthenogenesis. Sex ratios of parasitoids emerging from the 2nd and 3 rd instar host larvae were male biased, whereas from the 4th instar larvae and pupae sex ratios were female biased. For both species, the duration of the development time of egg, 2nd-3rd instar larva and pupal stages was influenced mainly by temperature. C. diallus required $17-18$ days at $26^{\circ} \mathrm{C}$ to complete development from egg to adult. C. pictus required 11,16 and 21 days at 26,21 and $16^{\circ} \mathrm{C}$, respectively. A brief description of courtship and mating (only in C. pictus), female oviposition and larval behaviour is reported.
\end{abstract}

Key words: behaviour, Eulophidae, Gracillariidae, host-mortality, Hymenoptera, Lepidoptera, life-cycle, longevity, sex-ratio

\section{Introduction}

The citrus leafminer (CLM), Phyllocnistis citrella Stainton (Lepidoptera: Gracillariidae) (formerly Phyllocnistis saligna Zeller and Lithocolletis citricola Shiraki) is native to India, China, and other southeast Asian countries (Clausen, 1931). It has spread rapidly since 1993 to all citrus-growing areas of the world (CABI, 1995; Hoy and Nguyen, 1997). It was first detected in Italy in 1995 (Benfatto, 1995) where it has been spreading through citrus growing regions. Because of the 
extensive mining of young shoots caused by this pest it is considered a serious threat to citriculture. Under typical Mediterranean conditions, CLM damage is of economic importance only on young and top-grafted trees, and is considered to be merely an aesthetic factor for mature trees (Gonzalez, 1997). In Sicily, Italy, the citrus leafminer is active during the summer and autumn months producing about 10 generations/year with a life-cycle of 15 days in the summer and 134 days in winter (Lo Pinto and Fucarino, 2000). Damage consists of mines on leaves, peduncles and flower calyces, causing flower abortium and sporadically, damage to young fruits (Liotta et al., 1996a). A number of indigenous natural enemies attack citrus leafminer in Sicily, including the Eulophid parasitoids; Pnigalio, Cirrospilus, Ratzeburgiola, Apotetrastichus, Chrysocharis, Neochrysocharis, Asecodes, Baryscapus, Elasmus and Semielacher genus (Liotta et al., 1996b). These parasitoid species were previously found on various wild hosts and started to attack $P$. citrella when it made its appearance. Several exotic species have also been introduced into Sicily (Mineo and Mineo, 1999). During the last 5 years, the main parasitoids found on P. citrella have been Cirrospilus spp., Semielacher petiolatus (Girault) and an exotic species, Citrostichus phyllocnistoides Narayanan (Liotta et al., 2003).

Previous field observations showed Cirrospilus diallus and C. pictus to be most common and widespread native parasitoids in Sicily, with parasitism levels usually around 10-15\% (Lo Pinto and Salerno, 1997). These species had already been reported as primary or secondary parasitoids of other lepidopterous, hymenopterous and coleopterous leafminers (Bouček and Askew, 1968). C. pictus has also been recorded on P. citrella in Spain (Garrido and Del Busto, 1994) and in Morocco (Abbassi in Caleca et al., 1995), whereas $C$. diallus has been reported on $P$. citrella only in Italy (Liotta et al., 1996b). Therefore, C. diallus and C. pictus might constitute new parasitoid/host associations not yet present in P. citrella's country of origin, thus leading to potential advantages for biological control purposes (Hokkanen and Pimentel, 1989). Our objective was to study the biology and foraging behaviour of these two species to improve their use as biological control agents. To this end we examined longevity, host mortality due to parasitoid stings, parthenogenesis, sex ratio in different host stages, stage development times, life-cycle, courtship and mating (observed in C. pictus only, because of the scarcity of individuals of C. diallus), and oviposition and larval behaviour of both parasitoid species in the laboratory. 


\section{Materials and methods}

P. citrella was reared on two-year old potted orange trees (Citrus aurantium L.) pruned to obtain homogeneous young flushes. When the oldest leaves of the new flushes measured about 4-5 cm, 4-5 plants were introduced into rearing cages of transparent Plexiglas $(60 \mathrm{~cm} \times 50 \mathrm{~cm} \times 50 \mathrm{~cm})$ in a climatic chamber at $27 \pm 1{ }^{\circ} \mathrm{C}, 65 \pm 5 \%$ R.H., and L:D 16:8 and left for 3 weeks. Such a long period allowed moths to emerge within the cage so that artificial re-infestation was not necessary. Leafminer adults used for the infestation of new plants were initially collected from different citrus orchards located in areas of western Sicily. Adult moths were fed with honey and water solution placed directly on plants. In order to use $P$. citrella larvae for parasitization, groups of 15 plants were exposed to about 200 adults of $P$. citrella. One day later, plants were removed and kept undisturbed for 1 week. Leaves with leafminer at suitable stages for parasitization (2nd, 3rd and 4th instar larvae and pupae) were used in the assays. To rear $C$. pictus and $C$. diallus, a group of six plants infested with $P$. citrella were introduced into a cage where 50 pairs of parasitoid wasps collected from citrus fields were released. Adults were fed with a honey and water solution and left undisturbed for 15 days. Different cages were used for each species. At the end of the exposure period, the plants were removed and their leaves collected, wrapped with tissue paper, and kept in a plastic bag until adult emergence. Emerged parasitoids were collected daily and either used in the assays or released into the rearing cages. All calculations were done using the SAS/STAT package (SAS Institute Inc., 1999).

\section{Longevity}

Newly emerged parasitoid adults were kept singly in glass test tubes (length $=7.5 \mathrm{~cm}$; diameter $=1 \mathrm{~cm}$ ) sealed with wet cotton and containing a small amount of food, and observed daily until death. Adults were fed either (1) sugar (glucose) or (2) honey, which absorbed the humidity from the wet cotton cap sealing the test-tube. In all, 116 adults (59 males and 57 females) of $C$. diallus and 194 adults (106 males and 88 females) of C. pictus were tested. A logrank test was used to compare wasp longevity using food type, sex, and species as independent variables. Pre-planned tests were also performed to compare average longevity values maintaining an overall significance level of $5 \%$, using a modified Bonferroni procedure (Hochberg, 1988). 


\section{Host mortality due to female stings}

Two day-old mated females (67 C. pictus and 64 C. diallus) were isolated singly on orange seedlings infested by 2 (14 and 18), 3 (15 and 11), 4 (12 and 13), 5 (14 and 11) or 6 (12 and 11) unparasitized $P$. citrella hosts (using larvae and/or pupae randomly) (numbers in brackets correspond to number replicates for $C$. pictus and $C$. diallus, respectively) enclosed in transparent polyethylene bags ventilated by means of a sponge placed in the opening. After $24 \mathrm{~h}$, the female was removed and the leaves with hosts were checked under the microscope in order to count living hosts, parasitized hosts and paralysed hosts (due to stings by females) without parasitoid eggs. Attack rates in each replicate were computed, and compared between wasp species and between different host/parasitoid ratios, using a logistic regression analysis with a binomial distribution for the error term.

\section{Parthenogenesis}

One day-old virgin females $(\mathrm{n}=15$ in $C$. diallus and $\mathrm{n}=18$ in C. pictus), were placed singly on orange seedlings infested by 20 unparasitized $P$. citrella hosts (2nd, 3rd and 4th instar larvae and pupae present in equal numbers), enclosed in transparent polyethylene bags ventilated by means of a sponge placed in the opening and allowed to oviposit for a maximum of 5 days. They were fed with honey and water solution. Leaves with parasitized hosts were checked daily under a microscope. Portions of leaf around the parasitized host were cut off, placed singly in a glass test tube (length $=7.5 \mathrm{~cm}$; diameter $=1 \mathrm{~cm}$ ) and observed daily. Upon emergence of parasitoids, new adults were sexed and counted.

\section{Sex ratio}

Twenty mated females of each parasitoid species were placed singly for two days on orange seedlings infested by unparasitized $P$. citrella hosts (2nd, 3rd and 4th instar larvae and pupae present in equal numbers) (6 for each stage) enclosed in polyethylene bags as described above. Portions of leaves having a single parasitized host were cut off, placed in glass test tubes (length $=7.5 \mathrm{~cm}$; diameter $=1 \mathrm{~cm}$ ), and observed daily. Upon emergence, the sex of all parasitoid adults obtained from each $P$. citrella stage was recorded. For both parasitoid 
species, the percentage of parasitized hosts leading to male or female adults was calculated for each host stage. Comparisons between data were done using a logistic regression analysis with a binomial distribution for the error term.

\section{Stage development times and life cycle}

Forty mated females of each parasitoid species were placed singly for one day on orange seedlings infested by unparasitized $P$. citrella hosts (2nd, 3rd and 4th instar larvae and pupae present in equal numbers), enclosed in bags as above. Portions of leaves having a single parasitized host were cut off, placed in glass test tubes (as above) and observed three times per day until the emergence of the adults. Tests were carried out at three temperatures, 26,21 and $16{ }^{\circ} \mathrm{C}$ with 361 males and 367 females $C$. pictus. Due to scarcity of $C$. diallus, 111 males and 109 females were observed only at $26^{\circ} \mathrm{C}$. Duration times of each development stage were compared by means of a Cox's regression.

\section{Behavioral observations}

Courtship and mating behaviour were studied in C. pictus alone. In order to obtain virgin parasitoid adults, portions of leaves having a single parasitized host were cut off, isolated in glass test tubes and observed until adult emergence. New parasitoid adults were sexed and provided with a honey and water solution. Then, 20 pairs were introduced singly into test tubes and observed under the microscope for about $30 \mathrm{~min}$. Behavioural sequences and postures of pre-copulatory, copulatory and post-copulatory courtship phases were recorded and quantified.

To observe the oviposition behaviour of $C$. diallus and $C$. pictus, two day-old virgin (15 of each species) and mated (15 of each species) females were placed singly in a Petri dish (diameter $=8.5 \mathrm{~cm}$ ) containing a leaf with unparasitized hosts and observed under the microscope for about $30 \mathrm{~min}$.

For tests of larval behaviour, we used the same method as that for the experiment on the stage development time. Every day, 20 immature individuals of each parasitoid species were observed under the microscope during the development period from eggs to pupae. External changes and behavior of each individual were recorded. 


\section{Results and discussion}

\section{Longevity}

As in many parasitoids (Godfray, 1993), longevity of both Cirrospilus species was strongly affected by food type $\left(\chi^{2}=353.69\right.$, $\left.\mathrm{df}=1, p<0.0001\right)$ (Figure 1). Similar to observations on Ratzeburgiola incompleta Bouček (Lo Pinto, 1997), sugar fed adults had a very short average life-span (average $C$. diallus males $4.89 \pm 0.39$ days, $\mathrm{n}=28, C$. diallus females $4.83 \pm 0.30$ days, $\mathrm{n}=29$; C. pictus males $3.66 \pm 0.30$ days, $\mathrm{n}=29$, C. picus females $4.44 \pm 0.53$ days, $\mathrm{n}=27$ ), whereas adults provided with honey survived for a long time (average $C$. diallus males $37.65 \pm 4.25$ days, $\mathrm{n}=31$, C. diallus females $32.96 \pm 4.08$ days, $\mathrm{n}=28$; C. pictus males $47.82 \pm 3.80$ days, $\mathrm{n}=77$, C. picus females $36.56 \pm 2.72$ days, $\mathrm{n}=61$ ). Wackers (2000) showed that some parasitoids have difficulty feeding from solid sugar residues, but the food used in our experiments absorbed the humidity present in the air in the test-tube (due to the wet cotton cap sealing the tube), and so it seems that adults were able to feed on sugar. No significant differences were found between the sexes $\left(\chi^{2}=1.58, \mathrm{df}=1\right.$, $p=0.208, \mathrm{n}=165$ males, $\mathrm{n}=145$ females), even though males had, on average, a higher longevity than females, and between species $\left(\chi^{2}=0.83\right.$, $\mathrm{df}=1, \mathrm{p}=0.362, \mathrm{n}=116$ C. diallus, $\mathrm{n}=194$ C. pictus $)$. However, differential longevity between sexes has been recorded in a number of

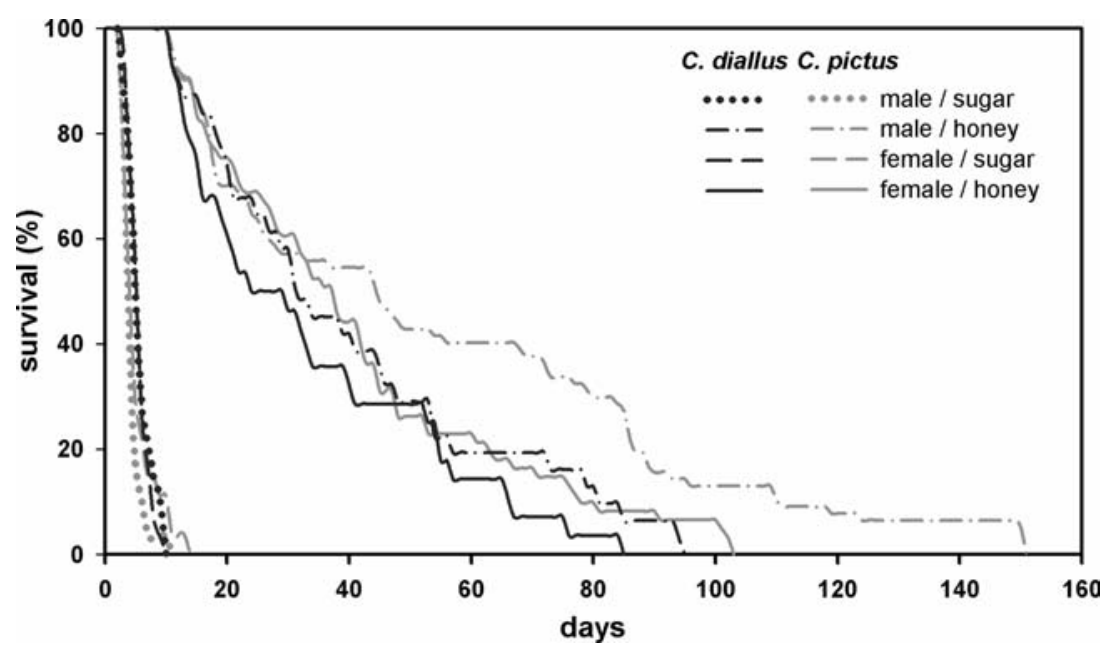

Figure 1. Survival functions of $C$. diallus and $C$. pictus adults fed with two types of food, sugar and honey. 
species of parasitoid wasps, with females in most cases suffering greater mortality (Godfray, 1993).

\section{Host mortality due to female stings}

No significant differences in host mortality were observed between the two species and the different host-parasitoid ratios (Figure 2) (all $\chi^{2}$, $p>0.05)$. For both Cirrospilus species, the number of hosts stung without oviposition was greater than the number of those with oviposition (about $70 \%$ of attacked hosts in all host-parasitoid ratios). It is likely that the greater number of hosts killed, but not parasitized, is due to factors such as probing with the ovipositor for the host selection and a sort of predation trough the host-feeding by females during their foraging. These aspects may represent an important contribution to control of $P$. citrella. Above all, host feeding by these parasitoids can cause significant leafminer mortality (Askew and Shaw, 1979).

\section{Parthenogenesis and sex ratio}

C. diallus and $C$. pictus virgin females laid eggs on the exposed hosts. Progeny obtained were males only, $45 C$. diallus and $51 C$. pictus, showing arrhenotokous parthenogenesis.

Mated females of both parasitoid species showed a similar pattern of male and female progeny allocation in different host stages

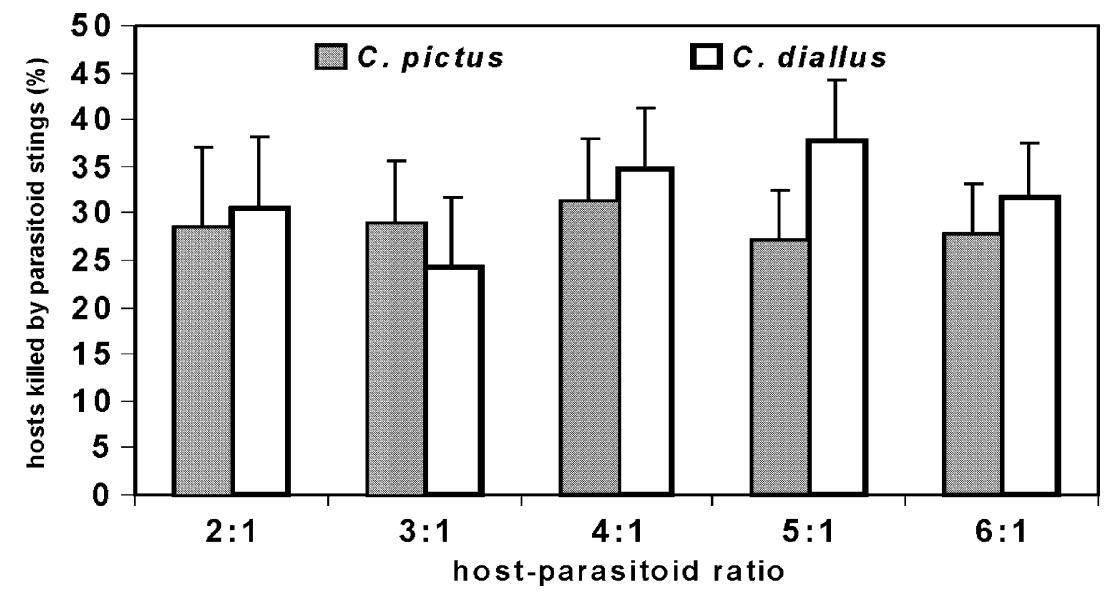

Figure 2. Average $(+\mathrm{SE})$ rates of $P$. citrella killed by parasitoid female stings of the two species $C$. pictus and $C$. diallus, under different host/parasitoid ratios. 


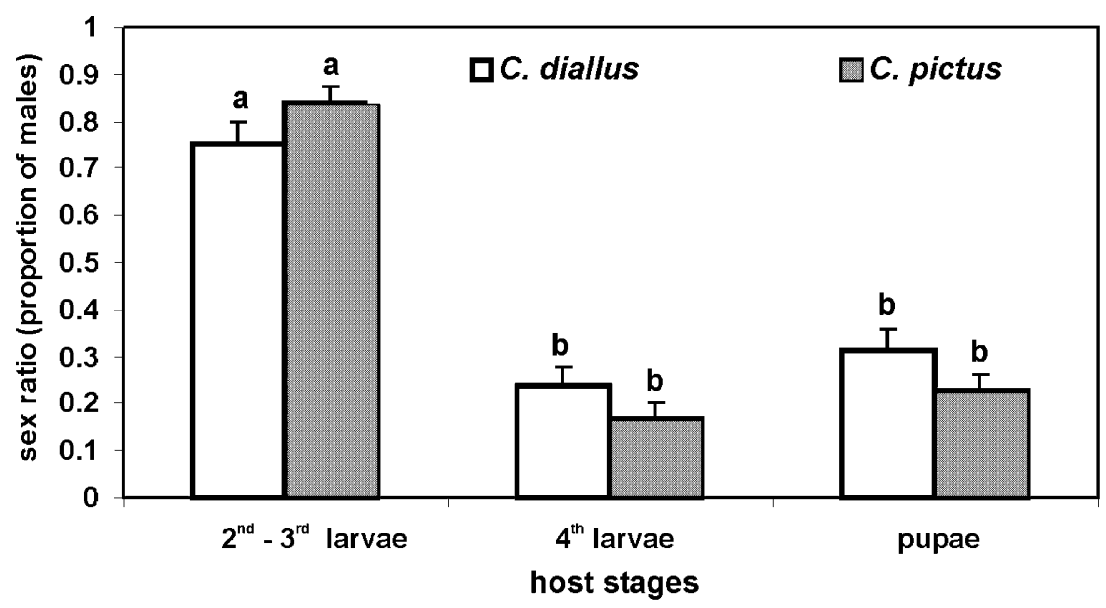

Figure 3. Sex ratio $(+\mathrm{SE})$ laid by the two species $C$. diallus and $C$. pictus females in relation to the different host stages exposed. Bars with different letters indicate significantly different percentage values ( $p<0.05$; logistic regression).

$\left(\chi^{2}=0.2, \mathrm{df}=1, p=0.636\right)$. When provided with a choice (Figure 3 ), both parasitoids laid a significantly greater proportion of male eggs in 2nd-3rd instar larvae than in 4th instar larvae $\left(\chi^{2}=43.9\right.$, $\mathrm{df}=1, p<0.0001)$ or pupae $\left(\chi^{2}=37.9, \mathrm{df}=1, p<0.0001\right)$. There was no significant difference in the proportion of male eggs laid between 4th instar larvae and pupae $\left(\chi^{2}=1.0\right.$, $\left.\mathrm{df}=1, p=0.316\right)$. Many parasitoid species lay male eggs in small hosts and females eggs in large hosts (Charnov, 1982), and the sex ratio may depend on host size determining the size of the adult parasitoid (Quicke, 1997). Waage (1982) and Werren (1984) suggested that the effect of host size on sex ratio is most likely to be found in species that attack non-growing host stages, or those preventing their hosts from continuing to grow (idiobionts). This is the case for both Cirrospilus species which lay their eggs on hosts after paralysing them permanently.

\section{Development times and life cycle}

Development times of the different stages, at three different temperatures, 26, 21 and $16{ }^{\circ} \mathrm{C}$ ) for $C$. pictus and, at $26^{\circ} \mathrm{C}$, for $C$. diallus, are presented in Table 1. The duration of egg, 2nd -3 rd instar larva and 4th instar larva, and pupal stages was significantly influenced by temperature $\left(\chi^{2}=47.8, \quad \mathrm{df}=2, p<0.0001, \chi^{2}=63.0, \quad \mathrm{df}=2, \quad p<0.0001\right.$, $\chi^{2}=16.2$, df $=2, p<0.001$, and $\chi^{2}=124.8$, df $=2, p<0.0001$, respec- 


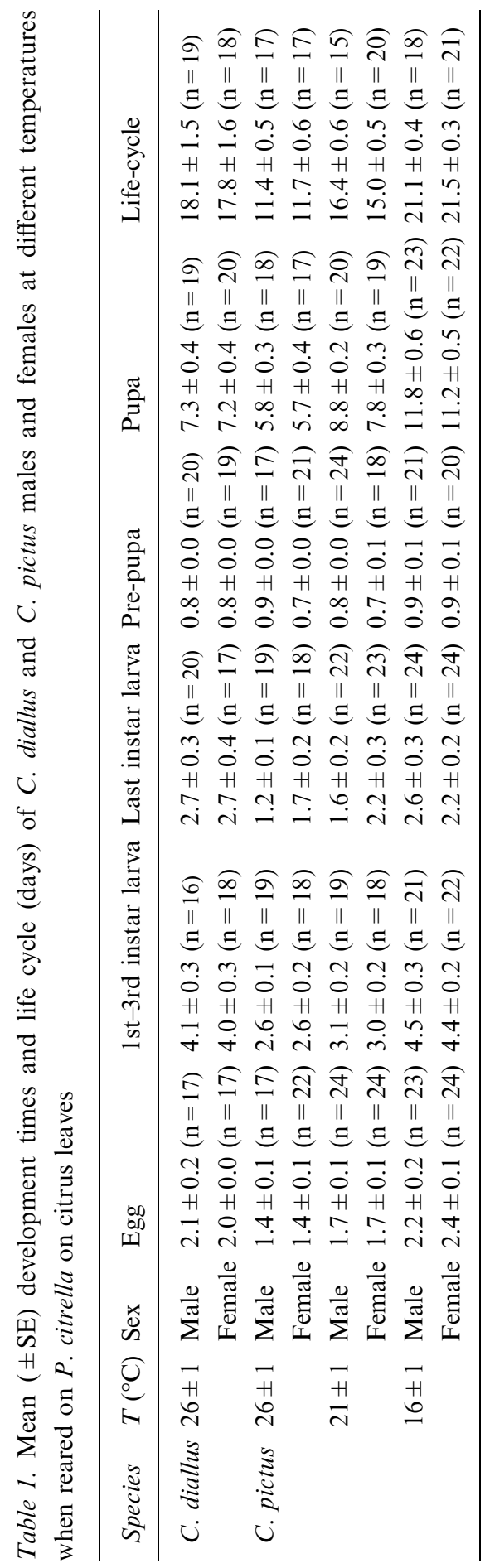


tively), whereas for the pre-pupal stage no significant differences were found $\left(\chi^{2}=3.5\right.$, $\left.\mathrm{df}=2, p=0.16744\right)$. This influence of temperature variation has been reported also for other eulophids (Bouček and Askew, 1968). Development times obtained were not statistically different between sexes for all stages (eggs: $\chi^{2}=0.4$, $\mathrm{df}=1, p=0.482,2 \mathrm{nd}-$ 3rd instar larva: $\chi^{2}=0.1, \mathrm{df}=1, p=0.721,4$ th instar larva: $\chi^{2}=1.9$, $\mathrm{df}=1, p=0.163$, pre-pupae: $\chi^{2}=0.5$, $\mathrm{df}=1, p=0.492$, pupae: $\left.\chi^{2}=1.1, \mathrm{df}=1, p=0.303\right)$. When development time was compared, at $26{ }^{\circ} \mathrm{C}$ between the two parasitoid species, significant differences were detected for all stages, except for pre-pupae, (eggs: $\chi^{2}=17.8, \mathrm{df}=1$, $p<0.0001,2 \mathrm{nd}-3 \mathrm{rd}$ instar larva: $\chi^{2}=37.6$, df $=1, p<0.0001,4$ th instar larva: $\chi^{2}=21.9, \quad \mathrm{df}=1, \quad p<0.0001$, pre-pupa: $\chi^{2}=0.1, \quad \mathrm{df}=1$, $p=0.701$, pupae: $\chi^{2}=27.8$, df $=1, p<0.0001$ ).

When comparing the life-cycle duration, significant differences were observed between the three different temperatures $\left(\chi^{2}=163.5\right.$, $\mathrm{df}=2, p<0.0001)$ and, at $26^{\circ} \mathrm{C}$, between the two species $\left(\chi^{2}=84.1\right.$, $\mathrm{df}=1, p<0.0001)$, but not between the sexes $\left(\chi^{2}=0.2\right.$, $\mathrm{df}=1$, $p=0.654)$. These aspects are quite common to most insect parasitoids, and similar results have been obtained from different Eulophid leafminer parasitoids (Llácer et al., 1998; Urbaneja et al., 1999).

\section{Behavioral observations}

Courtship and mating behaviour in $C$. pictus involves various actions and postures, and the likely exchange of sexual pheromones through antennal contact, wing and leg movements. These behaviours are often useful for identifying sibling species, or morphologically indistinguishable forms (Gordh and De Bach, 1978; van den Assem et al., 1982). C. pictus displayed typical behavioural sequences and postures characteristic of pre-copulatory, copulatory and post-copulatory courtship phases which included chemical signals. These cues play a very important role in mate recognition by hymenopterous parasitoids where males often show arrestant and short-range attractant responses to chemicals associated with females (Gordh and DeBach, 1978; van den Assem, 1986). During the pre-copulatory courtship, the C. pictus female remained motionless and the male touched the front or side of a female with its antennae, or along the female's side for about $30 \mathrm{~s}$, with likely female mates becoming receptive as a result of the male's courtship (Quicke, 1997). The male then mounted the female, and bending its head forward, its antennae vibrated and touched, or approached, the apices of the female's antennal clubs. Such antennal contact lasted from 1 to 10 minutes. Subsequently, the male 
placed its forelegs on the female's head and its posterior legs on the female's thorax, while the middle legs fluttered at the sides of the female's body for about $2-5 \mathrm{~min}$. The swaying middle legs were probably used to intermittently extend a pheromone to hinder the female's movements (Gordh and DeBach, 1978). During the copulatory phase, the male moved backwards, spreading its hind legs wide and touching the substrate. With its fore legs on the distal margin of the female's wings and its middle legs on the female's gaster, it bent its gaster under the female's to achieve genital contact. This phase lasted about 15-20 s. Like many parasitic wasps that spend a considerable amount of time in post-copulatory courtship (Allen et al., 1994), after copulation the $C$. pictus male removed its gaster and performed antennal movements on the female's wings, then climbed upon the dorsum of the female, assuming a position similar to that for pre-copulatory courtship. This phase lasted about $1-2 \mathrm{~min}$. It is likely that this behaviour is employed by the male as a way to prevent the female from mating with other males (Gordh and DeBach, 1978; Allen et al., 1994).

Oviposition behaviour appears similar in both Cirrospilus species. As for other parasitoid females (Godfray, 1993), host acceptance likely occurs by means of chemical cues perceived through receptors in the antennae, tarsi and ovipositor. Cirrospilus females searching for hosts walked on leaves with one or more mines, repeatedly touching the substrate with their antennae until a host was encountered. Generally, 2nd, 3rd, 4th instar larvae or pupae were selected. Females recognised potential hosts for the oviposition via external examination and, if the host seemed suitable, they then drilled it, perforating the mine cuticle and inserted the ovipositor in the host body. Occasionally, they stung the host body two or three times in different places. The sting lasted several seconds but was not always followed by oviposition. If the host was accepted, females drilled the leaf cuticle again with the ovipositor and laid an egg in contact with the host (78.45\% of the females), or within a distance of $6 \mathrm{~mm}$ from the host $(21.55 \%$ of the females). Oviposition lasted about $30 \mathrm{~s}$. Females sometimes returned to the same host to lay further eggs. Such superparasitism occurred in $26.7 \%(\mathrm{n}=49)$ of the parasitized hosts $(\mathrm{n}=183)$ in $C$. diallus and $37.2 \%(\mathrm{n}=73)$ of the parasitized hosts $(\mathrm{n}=196)$ in C. pictus. In the Eulophid family, such a phenomenon is often present and depends on the size of the host (Rizzo and Mineo, 2000). In all cases, as observed in other solitary species (Viggiani, 1964; Subba Rao and Ramamani, 1966), secondary larvae are often eliminated and only one individual reaches complete development, 
generally deriving from the first egg laid. The female's injection causes paralysis in the host. Larvae stung became motionless within half an hour and gradually took on a brown colour, swelled and subsequently died. This has already been observed in several parasitoids that release venom or a series of secretions associated with oviposition in hosts (Vinson, 1998) causing permanent paralysis and their death (Vinson, 1990; Quicke, 1997). Roundish melanic stains also appeared in the ovipositor's insertion points on the larvae body, as described in other eulophid species (Viggiani, 1964; Celli and Raboni, 1993).

Larvae show typical ectophagous behaviour. At the end of the incubation period, young larvae emerged from the chorion of the egg and attached themselves to the paralysed host, breaking through the host body cuticle with their mandibles. Larvae originating from eggs laid at a distance from the host (up to a $6 \mathrm{~mm}$ distance) were able to move towards the paralysed host and attack it. Plesiotropism of hatching larvae has been noted in Eulophidae (Bouček and Askew, 1968). Larvae feeding on the host body increased in size and took on a brownish colour. At the end of their growth the last instar larvae moved away from the host, rested, stopped at a short distance, and remaining under the leaf cuticle, expelled their faecal pellets for about $6-7 \mathrm{~h}$. Then, they changed into pre-pupa, which appeared completely whitish in colour and, after about $12-24 \mathrm{~h}$, the pupa gradually became darker, and finally brown. In $C$. pictus, the expulsion of faecal pellets was a typical characteristic because the last instar larva arranged the meconium in 3-6 small heaps around its own body with rotatory movements of its gaster. The characteristic distribution of faecal pellets in small heaps also occurs in other eulophid species (Viggiani, 1962) and is needed to prevent the mine collapsing, with consequent damage to the pupa, as it dries out.

\section{Acknowledgements}

We would like to thank Prof. S. Colazza of the University of Palermo, Italy, for the critical revision of the manuscript. 


\section{References}

Allen, G.R., D.J. Kazmer and R.F. Luck, 1994. Postcopulatory male behaviour, sperm precedence and multiple mating in a solitary parasitoid wasp. Anim. Behav. 48: 635-644.

Askew, R.R. and M.R. Shaw, 1979. Mortality factors affecting the leaf-mining stages of Phyllonoricter (Lepidoptera: Gracillariidae) on oak and birch: 1. Analysis of the mortality factors. Zool. J. Linnean Soc. 67(1), 31-49.

Assem, J. van den, 1986. Mating behaviour in parasitic wasps. In: J.K. Waage and D. Greathead (eds), Insect parasitoids. Academic Press, London. pp. 137-167.

Assem, J. van den, M.J. Gijswijt and B.K. Nubel, 1982. Characteristics of courtship and mating behaviour used as classificatory criteria in Eulophidae Tetrastichinae (Hymenoptera), with special reference to the genus Tetrastichus. Tijdschrift. Voor. Entomologie 125: 205-220.

Benfatto, D., 1995. La minatrice serpentina degli agrumi: un nuovo fitofago presente in Italia - L'Informatore Agrario 4(94): 79-80.

Bouček, Z. and R.R. Askew, 1968. Index of Entomophagous insects. Hym. Chalcidoidea. Paleartic Eulophidae. Ed. Delucchi and Remardiere. Le François, Paris. 254 pp.

Caleca, V., G. Lo Verde and H. Tsolakis, 1995. La minatrice serpentina Phyllocnistis citrella Stainton (Lepidoptera Gracillariidae Phyllocnistinae) un nuovo fitofago degli agrumi siciliani. Sviluppo agricolo 9(10), 33-45.

Celli, G. and F. Roboni, 1993. La paralizzazione negli Imenotteri Terebranti: il caso di Diglyphus isaea (Walker) (Hym. Eulophidae). Boll. Ist. Ent. "G. Grandi" Univ. Bologna 47: 135-140.

Charnov, E.L., 1982. The theory of sex allocation. Princeton University Press, Princeton.

Clausen, C.P., 1931. Two citrus leaf miners of the far east. Tech. Bull. 252, U.S. Department of Agriculture,Washington, DC.

Commonwealth Agricultural Bureau International (CABI). 1995. Distribution Maps of Pests. Series A: Map No. 274 (2nd revision).

Garrido, A. and T. Del Busto, 1994. Enemigos de Phyllocnistis citrella Stainton encontrados en Malaga; Investigacion Agraria, Produccion y Proteccion Vegetales. La Proteccion Vegetal en Espana. Fuera de Serie, 2. Min. de Agric., Pesca y Aliment. INIA.

Godfray, H.C.J., 1993. Parasitoids: Behavioural and Evolutionary Ecology. Princeton University Press, New Jersey. pp 473.

González, L., 1997. Daños causados por los ataques de Phyllocnistis citrella Stainton (Lepidoptera: Gracillariidae) y su repercusion sobre la produccion de [actute] arboles adultos decitricos en el suroeste español. Bol. San. Veg. Plagas 23: 73-91.

Gordh, G. and P. DeBach, 1978. Courtship behaviour in the Aphytis lingnanensis group, its potential usefulness in taxonomy, and a review of sexual behaviour in the parasitic Hymenoptera (Chalc. Aphelinidae). Hilgardia 46: 37-75.

Hochberg, Y., 1988. A sharper Bonferroni procedure for multivariate tests of significance. Biometrika 75: 800-802.

Hokkanen, H.M.T. and D. Pimentel, 1989. New associations in biological control: Theory and practice. Can. Ent. 121: 829-840.

Hoy, M.A. and R. Nguyen, 1997. Classical biological control of the citrus leafminer Phyllocnistis citrella Stainton (Lepidoptera: Gracillariidae): Theory, practice, art and Science. Trop. Lepid. 8(Suppl. 1), 1-19. 
Llácer, E., A. Urbaneja, J. Jacas and A. Garrido, 1998. Ciclo biológico de Quadrastichus sp., parasitoide exótico del minador de las hojas de los cítricos Phyllocnistis citrella Stainton, en laboratorio. Bol. San. Veg. Plagas 24: 669-678.

Liotta, G., A. Agrò and A. Lo Genco, 2003. Activity of indigenous and exotic parasitoids of Phyllocnistis citrella Stainton (Leidoptera: Gracillariidae) in western Sicily. IOBC WPRS Bulletin 26(6), 23-25.

Liotta, G., M. Lo Pinto, L. Di Trapani and S. Manzella, 1996a. Preferenza di Phyllocnistis citrella Stainton (Lepidoptera: Gracillariidae) nell'attacco agli organi suscettibili di Citrus spp. Atti Giornate Fitopatologiche 1: 47-52.

Liotta, G., E. Peri, G. Salerno, D. Di Cristina and S. Manzella, 1996b. Nemici naturali della minatrice serpentina degli agrumi. L'Informatore Agrario 8: 123-124.

Lo Pinto, M., 1997. Parassitismo e biologia di Ratzeburgiola incompleta Bouček (Hymenoptera: Eulophidae: Eulophinae) ectoparassitoide di Phyllocnistis citrella Stainton (Lepidoptera: Gracillariidae: Phyllocnistinae). Frustula entomol. n.s. XX(XXXIII): 184-192.

Lo Pinto, M. and G. Salerno, 1997. Ruolo dei parassitoidi indigeni di Phyllocnistis citrella Sianton (Lepidoptera: Gracillariidae) nella Sicilia occidentale. Phytophaga 7: 35-43.

Lo Pinto, M. and A. Fucarino, 2000. Osservazioni biologiche su Phyllocnistis citrella in Sicilia. Informatore Fitopatologico 3: 54-60.

Mineo, G. and N. Mineo, 1999. Introduzione di Citrostichus phyllocnistoides Narayanan in Sicilia e suo allevamento simultaneo con Semielacher petiolatus (Girault) (Hym. Eulophidae). Boll. Zool. Agr. Bachic. Ser. II, 31(2), 197-206.

Quicke, D.L.J., 1997. Parasitic Wasps. Chapman \& Hall, London.

Rizzo, M.C. and G. Mineo, 2000. Osservazioni sul comportamento delle femmine adulte e sullo sviluppo preimmaginale di eulofidi (Hymenoptera: Eulophidae) parassitoidi di Phyllocnistis citrella Stainton (Lepidoptera: Gracillariidae). Atti Accademia Nazionale Italiana Entomologia XLVIII: 259-270.

SAS Institute Inc., 1999. SAS/STAT User's guide. SAS Institute Inc., Cary, NC. Version 8.

Subba Rao, B.R. and S. Ramamani, 1966. Biology of Cirrospiloideus phyllocnistoides (Narayanan) and description of a new specie Scotolinx quadristriata (Hymenoptera: Eulophidae) as parasites of Phyllocnistis citrella Stainton. Indian J. Ent. 27(4), 408-413.

Urbaneja, A., E. LlÁcer, O. TomÁs, A. Garrido and J. Jacas, 1999. Effect of temperature on development and survival of Cirrospilus sp. near lyncus (Hymenoptera: Eulophidae), parasitoid of Phyllocnistis citrella (Lepidoptera: Gracillariidae). Environ. Entomol. 28(2), 337-344.

Viggiani, G., 1962. Contributi alla conoscenza degli insetti fitofagi minatori e loro simbionti. II. Studio morfo-biologico del Colastes braconius Hal. (Hym. Braconidae) e nota su altri entomoparassiti della Napomyza lonicerella Hend. (Dipt. Agromyzidae). Boll. Lab. Ent. agr. "F. Silvestri", Portici 20: 185-241.

Viggiani, G., 1964. Contributi alla conoscenza degli insetti fitofagi minatori e loro simbionti. IV. Morfo-biologia del Pediobius saulius Walk. (Hym. Eulophidae) e considerazioni sulle altre specie congeneri europee. Boll. Lab. Ent. agr. "F. Silvestri", Portici 22: 205-244.

Vinson, S.B., 1990. How parasitoids deal with the immune system of their hosts: an overview. Arch. Insect Bioch. Physiol. 13: 3-27.

Vinson, S.B., 1998. The general host selection behavior of parasitoid Hymenoptera and a comparison of initial strategies utilized by larvaphagous and oophagous species. Biol. Control 11: 79-96. 
Waage, J.K., 1982. Sex ratio and population dynamics of natural enemies - some possible interactions. Ann. Appl. Biol. 101: 159-164.

Wackers, F.L., 2000. Do oligosaccharides reduce the suitability of honeydew for predators and parasitoids? A further facet to the function of insect-synthesized honeydew sugars. Oikos 90(1), 197-201.

Werren, J.H., 1984. A model for sex ratio selection in parasitic wasps: local mate competition and host quality effects. Neth. J. Zool. 34: 81-96. 